\title{
Erken Cumhuriyet Döneminde Devletçilik: Ahmet Ağaoğlu ve Kadro Hareketi
}

\section{Özet}

Şebnem KORKMAZ ${ }^{1}$

Erken Cumhuriyet dönemi olarak tabir edilen 1923-1946 yılları arasında kalkınmanın nasıl gerçekleşeceğine dair farklı pek çok görüş bulunmaktadır. Bunlar; bireyi önceleyen liberal tarzda devlet anlayışı ve milli çıkarı birey çıkarından üstün gören tam müdahaleci devletçilik anlayışı olarak ifade edilebilir. Örneğin, 1932-1933 yıllarında liberal politikaların belirlenmesinde etkin olan Ahmet Ağaoğlu ve Marksist geleneğin ürünü olan Kadro hareketi arasında devletçilik ilkesi üzerine uzun soluklu tartışmalar yaşanmıştır. Ahmet Ağaoğlu hem bir fikir adamı hem de aktif siyasetin de içinde yer alan liberal tarzda milliyetçiliğin savunucularından biri olmuştur. Kemalizm'i sosyalist bir perspektiften ele alan Kadrocular ise milli çıkarlar için devletin her alanda var olması gerektiğini savunmuştur. Bu çalışmada devletçilik anlayışı, farklı pek çok yorumun aksine Ağaoğlu'nun liberal perspektifi ve Kadrocuların tam müdahaleci yaklaşımı ile incelenmeye çalışılmışıır. Osmanlı Devleti'nin yerine kurulan Türkiye Cumhuriyeti, savaş sebebiyle dağılan ekonomiyi yeniden canlandırmak için çeşitli ekonomi politikaları denemiştir. Özellikle 1929 Ekonomik Buhranı sonrası özel teşebbüsü reddetmeyen ancak devletin etkin bir konumda olduğu karma ekonomi metodunun benimsenmesinde liberal milliyetçi kanattan Ağaoğlu ve Marksist gelenekten gelen Kadro hareketinin tartışmalarının etkili olduğu görülmüştür.

Anahtar Kelimeler: Devletçilik, Ahmet Ağaoğlu, Liberalizm, Kadro hareketi, Ekonomi

${ }^{1}$ Yüksek Lisans Öğrencisi, Sakarya Üniversitesi, Siyaset Bilimi ve Kamu Yönetimi, Sosyal Bilimler Enstitüsü, Sakarya, Türkiye, ORCID: 0000-0003-4830-3118, sebnem-korkmaz@outlook.com 


\title{
Statism in The Early Republican Era: Ahmet Ağaoğlu and The Kadro Movement
}

\begin{abstract}
There were many different views on how the development would take place between the years 1923-1946, which is called the Early Republican period. One of them can be defined as the liberal approach to statism that prioritizes the individual, while the other can be expressed as a fully interventionist understanding of statism that sees national interests as superior to individual interests. For example, between 1932-1933, there were long debates on the principles of statism between Ahmet Ağaoğlu who was active in the determination of liberal policies, and the Kadro Movement which was a product of the Marxist tradition. Ahmet Ağaoğlu was not only an intellectual but also an advocate of liberal nationalism in the political field as an active participant. The Kadro movement, which approached Kemalism from a socialist perspective, argued that the state needs to be active in all fields for national interests. In this study, the understanding of statism has been tried to be examined with the liberal perspective of Ağaoğlu and the full interventionist approach of the Kadro movement, contrary to many different interpretations. The Republic of Turkey, which replaced the Ottoman Empire, has tried various economic policies to revive the economy that crumbled in the previous wars. Particularly, the debates between the Kadro movement from Marxist tradition and Ağaoğlu from the liberal nationalist wing were effective in the adoption of the mixed economy system, which did not refuse private investments but also put the state into the active role after the 1929 Economic Depression.
\end{abstract}

Keywords: Statism, Ahmet Ağaoğlu, Liberalism, The Kadro Movement, Economy

${ }^{1}$ Graduate Student, Sakarya University, Political Science and Public Administration, Institude of Social Sciences, Sakarya, Turkey, ORCID: 0000-0003-4830-3118, sebnem-korkmaz@ outlook.com 


\section{GİRISs}

I. Dünya Savaşı'nda yenilgiye uğrayan Osmanlı toprakları İtilaf Devletleri tarafindan işgal edilmiştir. Art arda gelen savaşlar devlet ekonomisi, iş gücü, toplumsal ve siyasal direnci yıpratmaya başlamıştır. Üretim yapan nüfusun savaşlarda hayatını kaybetmesiyle birlikte, ekonomik darboğazdan nasıl çıkılacağı büyük bir soruna dönüşerek Anadolu'nun giderek yoksullaşmasına neden olmuştur. Ekonomi alanındaki sorunlar, Anadolu topraklarına yönelik işgaller, yönetim eksikliği yeni bir devletin habercisi olmuştur. Osmanlı İmparatorluğu sonrası kurulan Türkiye Cumhuriyeti Devleti, yıpranmış bir ekonomi ve belirsiz bir siyasal sistemi devralmıştır. Yeni kurulan bu devletin sorunlara yönelik çözüm yollarının ne olacağ ise merak konusu olmuştur. Hem var olan sorunlar hem de Osmanlı Devleti'nden kalma borçlar nedeniyle kaygılanan Türkiye Cumhuriyeti Devleti ekonomi hamlelerini liberal anlayış çerçevesince şekillendirmiştir. Ardından 1929 Ekonomik Buhranı ve Lozan Anlaşması'nın getirdiği bazı sınırlılıkların kalkmasıyla birlikte 1931 yılında devletçilik ilkesine geçilmiştir.

Kriz etkisinde kalan birçok ülke tarafından çıkış yolu olarak görülerek uygulama alanı bulan devletçilik ilkesinin uygulanmasına dair çeşitli yorumlar yapılmıştır. Ziya Gökalp, Yusuf Akçura, Tekin Alp, Şevket Süreyya Aydemir, Ahmet Ağaoğlu, Ahmet Hamdi Başar, Recep Peker, İsmet İnönü gibi pek çok isim bu konu hakkındaki görüşlerini çeşitli gazete ve dergilerde yayınlamıştır. Görüldüğü üzere devletçilik konusu hem milliyetçilerin hem liberallerin hem de Marksistlerin ilgi odağı olmuştur. $\mathrm{Bu}$ bağlamda çalışmamız devletçilik konusunu, 1932-1933 yıllarında süregelen Ağaoğlu ve Kadro hareketi arasındaki çatışmadan esinlenerek liberal ve Marksist çerçevede incelemeyi gaye edinmiştir.

1932-1933 yıllarında Ağaoğlu ve Kadrocular arasındaki tartışmalarını Devlet ve Fert isimli eserinde derleyen Ağaoğlu, devletçiliğe ilişkin tüm görüşlerine de burada yer vermektedir. Bu kaynakta Şevket Süreyya Aydemir ve Yakup Kadri özelinde tüm Kadroculara yönelik eleştirilerini toplamıştır. Ağaoğlu ile ilgili ulaşılan ilk kapsamlı eser İki İmparatorluk Arasında A ğaoğlu ve Yeni Türkiye'dir. Ağaoğlu'nun hayatına, yaşadığı bölgelere, dönemsel koşullarına ve zihin dünyasına bu eserde rastlamak mümkündür. Ancak çalışma, Ağaoğlu'nun devletçilik ilkesine bakışını temel aldığından bu eser eksik ve yetersiz kalmıştır. İlgili makalelerde ise Ağaoğlu liberal, gazeteci, hukukçu gibi daha spesifik sayılabilecek kimlikler ile özdeşleştirilerek değerlendirilmiştir ${ }^{1}$. Kadro hareketinin devletçiliğe yönelik ifadelerine yer veren kaynaklar ise konuyu oldukça geniş açıdan ele almaktadır. "Kadrocular ve Sosyoekonomik Görüşleri” isimli eser Kadro hareketinin ortaya çıkışını, ideolojik arka planını, ekonomi ve siyasete ilişkin görüşlerini detaylı bir şekilde incelemektedir. Tarihsel süreç bağlamında Kadro hareketini ele alan bir diğer kitap ise Kadrocular ve Kadro hareketidir. Konu ile ilgili en geniş değerlendirmelere yer veren bu eser, 1930'lar Türkiye'sinden hareketle Kadronun doğuşunu, yazı ekibini, temel görüşlerini, ideolojisini, harekete gelen tepkileri, sonraki dönemlere olan etkisini değerlendirmektedir. İncelenen literatürde doğrudan Ağaoğlu ve Kadro hareketinin devletçilik anlayışını irdeleyen bir kaynağa ulaşılamamıştır. Bu bağlamda çalışmada, devletçilik ilkesi Ağaoğlu özelinde liberalizm ve Kadrocu yaklaşım ile ele alındığından özgün bir çalışma olarak değerlendirilmelidir.

Devletçilik ilkesinin iki farklı yorumunu konu edinen bu çalışmada araştırma soruları olarak şunlar belirlenmiştir;

1. Erken Cumhuriyet Döneminde devletçilik ilkesine geçiş nasıl olmuştur?

2. Ahmet Ağaoğlu'nun devletçilik ilkesine yönelik görüşleri nelerdir?

3. Kadro hareketinde devletçilik ilkesi nasıl yorumlanmaktadır?

4. Ağaoğlu ve Kadro hareketinin devletçilik algısındaki temel farklılıklar nelerdir?

$\mathrm{Bu}$ çalışma kapsamında, belirlenen araştırma soruları çerçevesinde devletçilik ilkesi Ağaoğlu ve Kadro perspektifince incelenmeye çalışılmıştır. Bir numaralı araştırma sorusu dahilinde çalışmanın ilk bölümü, erken Cumhuriyet döneminde liberalizmden devletçiliğe geçişi konu edinmektedir. Bu bölümde aynı zamanda dönemin devlet ve devletçilik algısı üzerinde de durulmaktadır. İki numaralı araştırma sorusu ise ikinci bölümün başlığını oluşturmaktadır. Bu başlık altında, Ağaoğlu özelinde liberal devlet

\footnotetext{
${ }^{1}$ Bkz: Haklı, S. Z. (2018). Erken Dönem Cumhuriyet’te Ahmet Ağaoğlu'nun Kemalizm’i Liberal Perspektiften Yorumlama Çalışmaları. Liberal Düşünce Dergisi, Cilt 23. Sayı 90: 35-57.

Hekimoğlu, V.S. (2018). Gazeteci Kimliğiyle Ahmet Ağaoğlu. Bitlis Eren Üniversitesi Akademik İzdüşüm Dergisi. Cilt 3. Sayı 1: 47-59.

Kayabaş, E. (2012). Bir Yavuz Hukukçu: Ahmet Ağaoğlu. İstanbul Üniversitesi Hukuk Fakültesi Mecmuası. Cilt 70. Say1 1: 441-452.
} 
yaklaşımı irdelenirken üç numaralı soru kapsamında üçüncü bölümde Marksist gelenekten gelen kadro hareketinin devletçiliğe yönelik yorumları analiz edilmiştir. Çalışmanın son kısmında ise dört numaralı araştırma sorusuna yanıt aranmıştır. Bu bölümde, Ağaoğlu ve Kadro geleneğinin devletçilik algıları karşılaştırılmış ve temel farklılıklar tespit edilmeye çalışılmıştır.

\section{Erken Cumhuriyet Döneminde Devletçilik}

Trablusgarp Savaşı, Balkan Savaşları ve hemen ardından gelen I. Dünya Savaşında elindeki tüm kaynakları tüketen Osmanlı İmparatorluğu ekonomik ve siyasal anlamda çöküş ile karşı karşıya kalmıştır. I. Dünya Savaşı mağlubiyeti sonrası 30 Ekim 1918'de Mondros Ateşkes Anlaşmasını imzalayan Osmanlı İmparatorluğu fiilen sonlanmış ve bu anlaşmadan kısa bir süre sonra yabancı güçler tarafindan Anadolu toprakları işgale uğramıştır. İşgal sonrası Osmanlı'nın tam anlamıyla sonlanmasına zemin hazırlayan Sevr Antlaşması imzalanmıştır. Bu anlaşmalar neticesinde varlığını sürdürememiş ve galip devletler tarafından toprakları paylaşılan Osmanlı İmparatorluğu yerini Türkiye Cumhuriyeti Devletine bırakmıştır.

Osmanlı'da 19.yy'ın ikinci yarısıyla birlikte başlayan ekonomik problemlerin yeni kurulan devlet açısından ciddi bir sorun teşkil edeceği açıktır. İlk dış borcunu 1854'te Kırım Savaşı sonrası İngilizlerden alan Osmanlı için ekonomi sahası içinden çıkılmaz bir hal almaya başlamıştır (Aşçı, 2016:1651). 1881'de "Duyun-u Ummumiye" isminde diş borçların denetimi ve devlet gelirlerinin kontrol altında tutulması amaciyla kurulan bu kurum da kötü giden ekonomik sürecin çözümü olamamıştır (Dikmen, 2005: 153). Osmanlı ekonomisini zora sokan tek etmen elbette savaşlar değildir. 1850'li yıllarda İngiltere tekelinde bulunan ve kısa süre içinde Amerika Birleşik Devletleri'ne (ABD) ve Avrupa ülkelerine yayılan "Sanayi Devrimi" tarıma dayalı olan Osmanlı ekonomisini daha da kötüleştirmiştir. Gelişen teknolojiye ayak uyduramama ilk olarak Osmanlı’nın ekonomi sahasındaki problemlerini arttırmıştır. Kısa süre sonra çözülemeyen ekonomik sorunlar siyasal alana sirayet etmiş ve toplum nezdinde de hoşnutsuzluklar yaşanmaya başlamıştır.

Siyasal, toplumsal ve ekonomi alanlarında baş gösteren sorunlar neticesinde 1922 yılında Osmanlı Devleti yıkılmıştır. Yeni kurulan Türkiye Cumhuriyeti Devleti, Osmanlı Devletinden maddi ve manevi anlamda değerli bir mirasla birlikte siyasal, toplumsal ve ekonomik sorunları da devralmıştır. Cumhuriyet hükümetinin en büyük problemi ise Osmanlı Devletinden kalan dış borçlar olmuştur (Yücel, 2017: 69). I. Dünya Savaşı'nı sona erdiren Lozan Anlaşması'nda Osmanlı Devleti'nin dış borcu Türkiye dâhil olmak üzere 15 ülkeye ${ }^{2}$ bölüştürülmüştür. Diğer devletler din ve kan bağı gerekçesiyle borcun büyük kısmının Türkiye Cumhuriyeti Devleti'nce ödenmesinde 1srarcı bir tutum sergilemiş ve nitekim öyle de olmuştur (Aşçı, 2016: 1654). Anadolu topraklarının içinde bulunduğu bu ekonomik durumu iyileştirmek adına yeni bir politikaya gerek duyulduğu düşüncesiyle hükümet tarafından çeşitli adımlar atılmıştır. 1923 İzmir İktisat Kongresi'nde ağırlık kazanan liberal görüş neticesinde devlet müdahalesi ve işletmeciliğinin minimum seviyede tutularak özel teşebbüs ve özel mülkiyetin ehemmiyeti ön plana çıkarılmıştır. Kısa bir süre sonra serbest piyasada sanayi gelişiminin sağlanması amacıyla 1927 yılında Sanayi Teşvik Yasası çıkarılmıştır. Cumhuriyetin ilk yılları, uygulanan ekonomi adımlarına bakıldığında liberal dönem olarak ifade edilebilir. Ancak devletin zaman zaman yasal ve kurumsal düzenlemeler ile piyasa müdahalelerinde bulunmuş olması salt anlamda bir liberal anlayıştan bahsetmemizi engellemektedir.

1923 yılında İzmir İktisat Kongresinin toplanması, 1924'te İş Bankası'nın, 1925'te ise Sanayi Maadin Bankası'nın kurulması, 1926'da özel sektör kuruluşları olarak Uşak ve Alpullu şeker fabrikalarının üretime başlaması ve son olarak 1927'de Teşvik-i Sanayi Kanunu'nun kabul edilmesi ekonomi alanındaki liberal zihniyetin örnekleri olarak ele alınırken; 1924'te Terakkiperver Cumhuriyet Fırkası ve 1930'da Serbest Cumhuriyet Firkası'nın (SCF) kurulması ise ilk siyasi liberal hamleler olarak değerlendirilebilir. (Sağlam, 1981:73; Berber, 2011:212). Ancak belirtmek gerekir ki dönemin hükümeti için liberal anlayış aslında bir tercih olmamıştır. Lozan Anlaşması gereğince hükümetin 1929 Ekim ayına dek gümrük vergi oranlarını değiştirme yetkisinin bulunmaması liberal politikaların uygulanmasını hükümet için zorunlu kılmıştır. Bu durum ülkede ithalat patlamasına neden olmuş ve buna bağlı olarak ekonomi sürekli dış açık vermeye başlamıştır. (Mutlu, 2011). Liberal ekonomi politikalarında yaşanan bunalımın yanı sıra Serbest Fırka denemesinin de etkisiyle Menemen'de

\footnotetext{
${ }^{2}$ Yemen, Irak, Hicaz, İtalya, Yunanistan, Bulgaristan, Ürdün, Asir, Arnavutluk, Yugoslavya, Suriye-Lübnan, Filistin, Necit, Maan (Aşçı, 2016:1653)
} 
yaşanan Cumhuriyet karşıtı hareketler ülkedeki kaygının giderek artmasına neden olmuştur (Ercoşkun, 2019: 116). Ülkedeki sosyo-ekonomik krizlerin yanında siyasi krizler de yaşanmaktadır. İç ve dış konjonktürdeki bu gelişmeler hükümetin politik ve düşünce sisteminde köklü değişiklikler yapması gerektiğinin sinyallerini vermiştir.

1929 yılında ABD'de başlayan “Ekonomik Buhran” kısa süre içinde Avrupa ülkelerini ve Türkiye'yi etkisi altına almıştır. Haliyle Türkiye Cumhuriyeti Devleti'nin liberal iktisadi düşüncesini sarsılmaya başlamıştır. Türkiye dâhil olmak üzere pek çok ülke ekonomik yapılarında, özellikle ekonomi politikalarında önemli değişiklikler yapmıştır. 30 Ağustos 1930'da İsmet Paşa, Sivas Demiryolu açılışındaki konuşmasında ekonomide "mutedil devletçi”" olduklarını ifade eden şu sözlere yer vermiştir; “.... Liberalizm nazariyatı bütün bu memleketin güç anlayacağ bir şeydir. Biz iktisadiyatta hakikaten mutedil devletçiyiz. Bizi bu istikamete sevk eden bu memleketin ihtiyacı ve bu milletin fitrî temayülüdür. Memleketin ihtiyaçları için herkes ve her yer hazineden çare arar. Elektriği yapılmayan şehir, limanı fena olan yer, iş bulamayan adam hükümeti muhatap tutar. Mutedil devletçi olarak halkın temayülâtına ve metâlibine yetişemiyoruz diye kusurluyuz. Devletçilikten büsbütün vazgeçip her nimeti sermayedarların faaliyetinden beklemeye sevk etmek bu memleketin anlayacağı bir şey midir? (Sağlam, 1981: 74)"

Mustafa Kemal Atatürk de İsmet Paşa'nın söylemine benzer ifadeleri Mayıs 1931 tarihinde gerçekleşen Cumhuriyet Halk Partisi'nin 3. Kurultayı'nda dile getirmiş ve bu kurultayda laiklik ve inkılapçıllğın yanı sıra devletçilik de parti ilkesi olarak kabul edilmiştir.

“... Fırkamızın takip ettiği program, bir istikametten tamamiyle demokratik, halkçı bir program olmakla beraber iktisadi nokta-i nazardan devletçidir. Bu itibarla firkamıza müstenit olan hükûmet-i Cumhuriyetin her nokta-i nazardan vatandaşın hayatiyle, istikbaliyle ve refahıyla alâkadar olması tabiidir. Halkımız tab'an devletçidir ki, her türlü ihtiyacı devletten talep etmek için kendisinde bir hak görüyor. Bu itibarla milletimiz tabayii ile firkamızın programında tamamıyla bir mutabakat vardır. Bu istikametten yürüyeceğiz. Ve muvaffak olacağımızda şüphe yoktur... (Uzun, 2016 :278)"

1929 Ekonomik Buhranı ve Lozan'ın Türkiye'ye getirdiği bazı sınırlılıklarının kalkmasıyla birlikte pek çok gelişmiş ülkede olduğu gibi liberal düşünce yerini devletçilik politikasına bırakmıştır. Türk Dil Kurumu'na (TDK) göre devletçilik; bir milletin yönetimle ve ekonomiyle ilgili işlerinin devlet eliyle bütünleştirilmesi olarak tanımlanmaktadır. Devletçilik ilkesi ile devletin öncü olduğu ve sanayiye dayalı bir ekonomik gelişim hedeflenmiştir. Ancak bu durum özel teşebbüsün tam anlamıyla reddi demek değildir. Zaman zaman özel sektöre krediler temin ederek destek verildiğine dair örneklere de rastlamak mümkündür (Pamuk, 2012: 175). Bir diğer ifadeyle özel teşebbüs ve devlet desteğinin harmanlandığ1 Türkiye şartlarına uyarlanan karma bir sistem meydana getirilmiştir. Temel amaç ülkenin kalkınması olduğundan bunun devlet veya özel teşebbüsle olması pek önemli görülmemiştir.

Belirlenen yeni ekonomi çizgisinde yerli işletmeler desteklenmiş, yabancı sermayedarlardan milli çıkarlara uygun olanlara izin verilmiş, resmi döviz alımları ve yurtdışına para çıkışı durdurulmuş, ithalat devlet eline geçmiş ve sınırlandırılmış, gümrük vergileri arttırılmış ve ülkedeki azınlıklara yönelik yeni vergi düzenlemeleri yapılmıştır (Özlü, 2009:128). 1932 yılında çıkarılan bazı kanunlar özel teşebbüsün hareket serbestisini kısıtlamaya ve menfaatlerini zedelemeye yöneliktir. Bu doğrultuda çıkarılan kanunlar (Sağlam, 1981: 76);

- Devlet Sanayi Ofisi’nin Kuruluşu

- Sanayi ve Kredi Bankası'nın Kuruluşu

- Türkiye İskele ve Limanlar Arasında Posta Seferleri Hizmetinin Devlet İdaresine Alınmasına Dair Kanun

- Hükümetçe Ziraat Bankası'na Mubayaa Ettirilecek Buğday Hakkında Kanun.

1932 yılında Celal Bayar'ın İktisat Bakanı olmasıyla birlikte devletçi uygulamalar ortadan kaldırılamasa da bir nebze olsun hafiflemiştir (Boratav, 2006: 73). Devlet Sanayi Ofisi, iş adamlarını endişeye sürükleyen hamlelerde bulunurken; Bayar ehemmiyetin farkına varmış ve bu durumun geçici olduğunu, ülkenin gelir seviyesi arttığında devlet fabrikalarının kendilerine devredileceğini ifade etmiştir. (Sağlam, 1981: 81).

Türkiye her ne kadar sanayi ile kalkınmayı öncelikli görse de tarım toplumu olması ve çiftçi nüfusunun fazla olması gibi sebeplerden ötürü tarım alanında da yeni düzenlemeler yapmak zorunda kalmıştır. 
Tarım ürünlerinin fiyatlarını arttırmaktansa imalatın teşvik edilmesine yönelik maliyetler düşürülmüştür. Üretim artışına yönelik bu hamlenin ardından tüketimi de kontrol altında tutmak ve halkın yerli malı kullanımını sağlamak amacıyla 1929 yılı sonunda Milli Iktisat ve Tasarruf Cemiyeti kurulmuştur (Ezer, 2010: 431).

Türk parasının değer kaybetmesini önlemek ve ithalat-ihracat dengesini sağlamak gibi amaçlar doğrultusunda devlet, müdahalelerini arttırmıştır. Ancak piyasadaki para akışını kontrol etmek isteyen hükümetin para basma yetkisi bulunmamaktaydı. Bu yetki İngiliz-Fransız ortaklığındaki Osmanlı Bankası'nda olduğundan devletçilik ilkesinin tam anlamıyla uygulanamadığı yorumu yapılabilir. Ekonomi alanındaki etkinliğini arttırmak isteyen devlet 1930'da Merkez Bankası'nı kurmuştur. Ardından 1932'de Sanayi ve Kredi Bankası Sümerbank ismiyle piyasadaki yerini almıştır (Kahraman, 2005: 22).

Ülke ekonomisinin kalkınması amacını güden hükümet aynı zamanda 1930'lu yıllarda çok partili hayat denemesinde de bulunmuştur. Muhalefet eksikliğini hisseden Mustafa Kemal Atatürk, Fethi Okyar'dan bir parti kurmasını istemiştir. 12 Ağustos 1930 tarihinde Serbest Cumhuriyet Fırkası kurulmuştur. Halk, tek parti yönetiminden bunalmış, ağır vergiler altında ezilirken SCF, ekonomi politikasını liberalizm üzerinden şekillendirmiştir (Mutlu, 2011). Böylesi bir ortamda doğan SCF kısa sürede büyük kitlelere hitap etmeyi başarmıştır. Kısa sürede destek bulan SCF, Cumhuriyet Halk Partisi (CHP) tarafından gericilikle suçlanmış ve parti üç ay sonra kapatılmıştır. Çok partili hayata geçişin sağlanamaması elbette ki ekonomi alanına da olumsuz anlamda sirayet etmiştir. Hükümetin katı ekonomi politikaları, muhalefetin eksikliği nedeniyle sorgulanamamakta ve halkı zor düşürmektedir.

Çok partili hayata geçişin sağlanamaması ve yasal düzenlemelerin krizden çıkışta yetersiz kalması daha kalıcı ve planlı bir arayışa sebebiyet vermiştir. Bu anlamda Sovyet Rusya model alınmış ve devletçilik uygulamasının ilk somut örneği sayılan Birinci Beş Yıllık Kalkınma Planı (1933-38) oluşturulmuştur. $\mathrm{Bu}$ plan ile yerel veya bölgesel tarıma dayalı sanayi üretim birimlerinin kurulması, yerli malı kullanımına öncelik verilmesi ve sanayi kuruluşlarının hammadde ve işgücüne yakın yerlerde kurulması amaçlanmıştır (Kepenek, 1995: 61). Planın amaçları doğrultusunda dokuma, maden, selüloz, seramik ve kimya sanayilerine yatırımların yapılması öngörülmüsştür. Beş Yıllık Kalkınma Planı'nın başarı ile uygulanması sonrası 1938-1946 yılları arasında uygulanması düşünülen ve çok daha geniş kapsamlı olan İkinci Beş Yıllık Kalkınma Planı hazırlanmıştır (Özyurt, 1981:135). Ancak İkinci Dünya Savaşı'nın yarattığı olumsuz hava sebebiyle ikinci plan başarı ile neticelenememiştir.

Genel olarak toparlamak gerekirse; Türkiye Cumhuriyeti'nde devletçilik ilkesine geçiş 1929 yılı ekonomik buhranı ve Lozan Anlaşması'nın getirdiği bazı sınırlılıkların kalkması ile birlikte olmuştur. Devletçilik ilkesine geçişe dek özel teşebbüse dayalı kalkınma stratejisi izlenmiştir. Özel teşebbüsü reddetmeyen karma bir ilke inşa edilmiş ve bu model ile çeşitli kurum ve kuruluşlar kurulmuş, yeni yasal düzenlemeler ve kalkınma planları uygulanmıştır. Ancak Osmanlı Devleti’nden kalan mali sorunlar, halkın ağır vergi yükü altında kalması ve daha da önemlisi İkinci Dünya Savaşı'nın patlak vermesi devletçilik ilkesinin başarısını sınırlandırmıştır.

\section{Ahmet Ağaoğlu'nun Devletçilik Anlayışı Üzerine}

1869 yılında Şusa kentinde doğan ve 1939 yılı mayıs ayında İstanbul'da hayatını kaybeden Ahmet Ağaoğlu yetenekli, zeki, inançlı ve kariyer sahibi bir isim olmasının yanında 1905 Rus Devrimi, Birinci Dünya Savaşı, Kurtuluş Savaşı gibi pek çok tarihi olayı bizatihi yaşamıştır. Hayatının farklı dönemlerini farklı ülkelerde geçirmesi düşünce dünyasının şekillenmesinde büyük rol oynamıştır. Bu noktada özellikle Paris’te geçirdiği yılların Ağaoğlu üzerindeki etkisinin altını çizmek gerekecektir. Hayatının ilk yıllarını Rus hakimiyetindeki Azerbaycan'da geçiren Ağaoğlu annesinin 1srarı üzerine 1888'de Paris'e gitmiştir. 1894 yılına kadar Paris’te kalan Ağaoğlu, Ernest Renan'ın bireysel özgürlük, eleştirel düşünce ve laikliği esas alan görüşleri ve Renan'ın tavsiye mektubuyla Juliette Adam'ın salonunda bireysel haklar ve serbest ekonomiye dayalı fikirleri ile burada karşılaşmıştır (Shissler, 2005: 119). Yalnızca Paris'teki isimler değil Kafkasya'da geleneksel okulları reforme eden Gaspıralı İsmail Bey, İslam ve milliyetçilik anlayışının harmanlanmasında etkin olan Afgani ve Ortadoğu'nun Voltaire olarak bilinen Ahundzade gibi isimler Ağaoğlu'nun siyasal ve toplumsal düşüncelerinin gelişiminde etkili olan isimlerdir (Shissler, 2015: 161).

Ağaoğlu, Kafkasya'daki Rus baskısına dayanamamış ve Rusya Müslümanlarının birleşmesi ve ilerlemesi için pek çok gazete ve dergide yayın yaparak bazı örgütlenmelerde bulunmuştur (Yüce,1988: 465). Bunu bir tehdit olarak gören Ruslar, Ağaoğlu'nun sürülmesi gerektiği yönündeki söylemlerini 
yaygınlaştırmıştır. Ancak Ağaoğlu bu karar alınmadan Anadolu topraklarına gelmiştir (Atalar, 2018:141). İstanbul'a gelişiyle birlikte Türkçülük akımıyla tanışmıştır. Sonrasında ise Ağaoğlu'nda Cumhuriyet döneminde Batıcılık temelinde bireysel özgürlük ve hürriyet savunusu ağır basmıştır. Özetle Ağaoğlu İslamcılık ile başlayan fikir dünyasını Türkçülük ile devam ettirmiş ve Batıcılık ile sonlandırmıştır (Gündoğdu, 2020:17-22). Osmanlı İmparatorluğu'nun son dönemleri ve Türkiye Cumhuriyeti Devleti'nin ilk yıllarında hayatını idame ettiren Ağaoğlu, zihin dünyası ile Türk siyasi hayatında kritik noktalarda bulunan önemli bir isim olmuştur. II. Meşrutiyetin ilanından sonra 1909 yılında Türkiye'ye gelen Ağaoğlu, Maarif Müfettişliği, Süleymaniye Kütüphanesi Müdürlüğü, Darülfünun' da Rusça öğretmenliği ve Türk Tarihi müderrisliği görevlerinde bulunmuştur. Bunun yanı sıra Türk Derneği, Türk Yurdu ve Türk Ocağı gibi derneklerin kuruluşunda yer almış, Hikmet, Sebilürreşat, Tercüman-1 Hakikat, Türk Yurdu ve İslam gibi gazete ve dergilerde yazılar yayınlamıştır (Hekimoğlu, 2018:54). Paris'te İttihatçılar ile tanışan Ağaoğlu, İstanbul'a geldiğinde tekrar görüşme firsatı bulmuş ve kısa süre içinde bu harekette yer almıştır. Ancak İttihatçı sürgünlerinin başladığg $o$ yıllarda Ağaoğlu da Malta'ya sürülmüştür.

Türk siyasi hayatı açısından önemli bir yere sahip olan Ağaoğlu Cumhuriyetin ilk yıllarında liberal düşüncenin şekillenmesinde büyük rol oynadığı gerekçesiyle liberal kimliği ön plana çıkarılan bir isim olmuştur. ${ }^{3}$ Ferdi önceleyen, hürriyet ve dayanışma kavramlarına önem veren Ağaoğlu'nun liberalizm anlayışında Durkheim sosyolojisinin etkili olduğu söylenebilir (Özavc1, 2014:129-131). Ağaoğlu siyasi ve toplumsal düzen tesisi için bireycilik ve dayanışma kavramlarını bir arada kullanan bir yaklaşımı yararlı görmektedir. Serbest piyasadaki aşırı bireycilik düzeni bozacaktır. Bu nedenle dayanışmaya ihtiyaç duyulmaktadır diyen Durkheim ile Ağaoğlu'nun aşağıdaki ifadesinin açıkça örtüştüğü görülmektedir.

"Yüksek ferdiyet, serbest saha üzerinde serbest çalışmak, serbest ortakllk ve serbest rekabet esaslarına dayanmaktadır. Bu esasları ilk önce Büyük Fransız İnklabı uygulamaya başladı ve o zamandan beri Batı'da aile, devlet ve cemiyet teşkilatının hepsi bu esaslardan ilham almaya koyuldu. Her hakka karşı vazife ve her vazifeye karşı bir hak; işte bu esasların taşıdığı mana! Artık ne vazifesiz hak ve ne de haksız vazife vardır" (akt. Civelek, 2020: 374).

Cumhuriyetin ilk yılları Osmanlı Devleti'nden miras kalan sorunların çözümü yani devletin nasıl kurtulacağı sorusuna cevap aramakla geçmiştir. Bu noktada ferdin haklarını devletten daha mühim olarak gören Ağaoğlu liberal kimliği ile çözüm yolları aramıştır;

"Türk milletinin Batı medeniyetine erişmesinin tek çaresi, bu medeniyeti meydana getirmiş

olan serbest teşebbüs prensibinin samimiyetle kabulünden ibarettir.” (Ăgaoğlu, 1998:26-

27).

Liberal çerçevede görüşlerini ifade eden Ağaoğlu, siyaset hayatına CHP içinde başlamıştır. Parti içinde siyasal ve iktisadi anlamda liberal ilkeleri savunmuştur. Eserleri incelendiğinde özellikle birey, bireysel özgürlük, çoğulcu ve rekabetçi demokrasi gibi kavramlara yer verdiği görülmüştür (Kayabaş, 2012:444).

Tek parti döneminin baskıcı tutumu, bireysel hak ve özgürlükleri yok sayan politikaları Ağaoğlu'nu rahatsız etmekteydi. Özellikle İsmet İnönü başkanlığındaki CHP, Ağaoğlu'nun eleştiri oklarının hedefi olmuştur. Mustafa Kemal, CHP'nin bu sert tavırları karşısında bir muhalefet görmek istediğini beyan ederek 1930 yılında SCF’nin kurulmasını istemiştir. Ahmet Ağaoğlu kurulan muhalefet partisinin ilk üyesi olmuştur (Shissler, 2005: 304). CHP'den SCF'ye geçiş İnönü ile olan gerginliği giderek arttırmıştır. İsmet Paşa hükümetinin devletçi politikalarını eleştiren Ağaoğlu "Akın Gazetesi'ni çıkarmaya başlamıştır (Hekimoğlu, 2018: 56). Özellikle özgürlüklerin sınırlanmasını ve demiryolu politikasını eleştiren Ağaoğlu, SCF'nin anarşi ortamı yarattığı, gericilerin kuklası olması gibi suçlamalar ile kapanmasının ardından gazetesini de kapatmak zorunda kalmıştır (Atalar, 2018: 142).

1929 yılına kadar liberal çizgide olmaya çalışan hükümet, Büyük Buhran sonrasında pek çok ülke gibi devletçilik ilkesini benimsemiştir. Devletçiliğin ilke olarak kabul edilmesinin ardından parti içinde tartışmalar başlamıştır. Kemalizm'i sosyalizm üzerinden değerlendiren Kadro Dergisi ekonomik sıkıntıyı serbest piyasa ekonomisine dayandırmaktadır. Bu sebeple devletin piyasaya müdahalesini olumlu karşılamaktadır (Orhan, 2009:122). Ağaoğlu ise hükümetin tüm ekonomik alanlara

\footnotetext{
${ }^{3}$ Ancak Shissler'in Ağaoğlu'nu konu edindiği eserinde kendisini kozmopolit olmayan liberal-milliyetçi olarak tanımladığını belirtmek faydalı olacaktır (Shissler, 2005:124).
} 
müdahalesini öngören devletçilik anlayışına ciddi eleştiriler yöneltmiştir. Özellikle 1930'lu yıllarda Kemalizm'i sosyalist pencereden ele alan Kadro hareketinin devletçilik anlayışı ile mücadele eden Ağaoğlu, "Devlet ve Fert" isimli eserini yazmıştır.

Liberal kanatta yer alan Ağaoğlu devletin iki temel görevi olduğunu ifade ederek piyasa müdahalesine karşı çıkmaktadır. Ağaoğlu'na göre devletin ilk görevi düzeni korumak, ikincisi ise eğitim hizmeti sunmaktır. Devlet düzeni korumak adına sadece güvenlik tesis etmekle yükümlü kalmayarak siyasal alanın ilerlemesini de sağlamalıdır. Devletin birey özgürlüklerini tanıması ve bunları güvence altına alması konusuna dikkat çekmektedir (Ağaoğlu, 1933:40). İkinci görevinde ise devletin demokratik bir ortamı tesis etmesi için ilk olarak eğitimli bireyler yetiştirmesi gerektiğine vurgu yapmaktadır. Ağaoğlu'nun görüşüne göre ancak ve ancak kendi kararlarını alabilecek zihin ve ahlaka erişen birey, demokratik siyasal sistemi yaracaktır. Bu bağlamda halkevlerinin açılmasını desteklediğini ifade etmek yanlış olmayacaktır.

Ağaoğlu devletçilik ilkesinin tercih edildiği pek çok ülkenin ekonomik sınıfları arasındaki farklılıkları sebebiyle devletin müdahalesine ihtiyaç duyduğunu belirtir. Türkiye'de sınıf mücadelesi olmadığını ve bu sebeple özel teşebbüslere ve yabancı sermayeye devlet müdahalesinin yanlış bir politika olduğunu ifade etmektedir (Ağaoğlu, 1933: 62).

Ağaoğlu kendini kemalist, inkılapçı, demokrat olarak tanımlarken, Kadro tarzı devletçi olmadığını, liberal devletçiliği savunduğunu ifade etmektedir (Ağaoğlu, 1933: 101). Tamamen devlet eliyle planlanan bir ekonomi ile gelişmenin mümkün olmayacağını, girişimci bireylerin destekleri ile ilerlemenin modern devlet olmanın bir özelliği olduğunu belirtir (A ğaoğlu, 1933:17-18). Genel anlamda Ağaoğlu'nda devletçilik anlayışını, bireylerin yapamayacağı işleri üstlenen ve kalan işleri bireylere bırakan bir yapı olarak ifade edebiliriz.

\section{Kadro Hareketi'nde Devletçilik Anlayışı}

Şevket Süreyya Aydemir, 1930'lar Türkiye'sinde öne çıkan Kadro hareketinin sözcülüğünü yapmış önemli isimlerdendir. Devletçilik ilkesine geçişten hemen sonra Ahmet Ağaoğlu ile 1932-33 yılları arasında ciddi tartışmalara giren Aydemir, yazılarını Kadro Dergisi'nde yayınlamışıtır (Shissler, 2005:314). Kadro Dergisi yayın hayatını sonlandırana dek Şevket Süreyya, Vedat Nedim, İsmail Hüsrev, Burhan Asaf, Şevki Yazman ve Yakup Kadri'nin yer aldığı bir yazı ekibi ile varlığını sürdürmüştür. Kadro hareketi Kemalizm'e ideolojik bir çerçeve yaratma amacı gütmüş ve bu sebeple tek parti döneminin pek çok uygulamasını -baskıcı, sınırlayıcı olsa dahi- haklı bulmuş ve gerekçelendirmeye çalışmıştır. Nitekim 15 Ocak 1931'de Türk Ocakları Genel Merkezi'nde Aydemir yaptığı konuşma bu ifadeyi destekler niteliktedir.

"Konferansın basılması ve bütün şubelere dağıtılması arzusu belirdi. Fakat Ocak'ta başlayan tartışmaların Ocak dişına yayllmasıyla beraber aldığı yön ve bazı gazeteler tarafindan bu konferansın CHP içinde yeni bir ideoloji cereyaninın başlangıcı şeklinde yorumlanması, bizi bu tartışmalar yayginlaştırmaktan çekinmeye ve konuyu, daha anlaşılır bir şekilde işlemeye sevk etti." (Keser, 1993:126).

Bu bağlamda 1929 Ekonomik Buhranı sonrasında liberalizmin yerine devletçilik ilkesinin kabulü de Kadro hareketi ve savunucuları tarafından olumlu karşılanmıştır. Kadrocu yaklaşımın temelleri Marksist öğretiye dayalı materyalizmdir (Bostancı, 1990:54). Sınıf çelişkisi üzerinde duran Kadrocular, kapitalizmin batıya özgü olduğunu, Türkiye'ye uymadığını savunmuştur. Kemalist hareketin gerçekleştirdiği devrimler sınıfsız ve tezatsız bir ulus yaratma amacında olmuştur (Bostancı,1990: 55). $\mathrm{Bu}$ amaç doğrultusunda Aydemir başta olmak üzere tüm Kadro hareketinin devletçilik anlayışının devletin tüm alanlara müdahalesi yönünde şekillenmesi kaçınılmaz olmuştur.

"Sanayiyi kurmak fakat sinı mücadelesini önlemek milli sermayeyi yaşatmak, fakat bu sermaye üstünde bir oligarşinin şımarıklı̆ına yol açmamak, devleti geliştirmek, fakat ferdi köle haline getirmemek... (Aydemir, 1959: 499; akt. Keser, 1993: 137)"

Aydemir'in ifadeleri Kadro hareketinin devletçilik anlayışının temellerini açık ve net bir şekilde sunmaktadır. Aydemir'e göre üretim araçları devletin gücüyle milli çıkarlar çerçevesinde işletileceğinden sınıflar meydana gelmeyecektir. Ekonomik kalkınma ve gelişme sürecinde kapitalizmi

\footnotetext{
${ }^{4}$ Ağaoğlu'nun liberal olarak anılması SCF'ye girişi, bu dönemlerde Cumhuriyette hür ve özgür bir ferdin nasıl yaşayacağını anlatan Serbest İnsanlar Ülkesinde (Ağaoğlu, 1930:2) isimli eseri ve 30'lu yıllardaki devletçilik adına gerçekleştirdiği tartışmalara dayandırılmaktadır (Yılmaz, 1993:60).
} 
öngören Aydemir, sınıf çatışmasının önlenmesi noktasında devlet müdahalesinin Türk tarihi açısından geleneği olan bir uygulama olarak düzenin sağlanması noktasında gereklilik arz ettiğini ifade etmektedir (Keser, 1993: 130; Bostanc1, 1990:58). Bunlara ek olarak kriz ortamını piyasa ekonomisine dayandıran Aydemir, devlet müdahalesi ve planlamalarını çıkış noktası olarak ifade etmektedir. Ülke ekonomisinin kalkınması hususunda ise, hızlı sanayileşmenin ancak ve ancak devlet aracılığıyla mümkün olabileceğini belirtmektedir.

Genel anlamda Kadro hareketinin devletçilik görüşleri;

- Devletçilik, Marksist etki üzerinde şekillenmiştir. Bu doğrultuda anti-emperyalist, batı karşıtlığı olarak ifade edilebilir.

- Devletçilik ilkesini halkçılık ilkesi ile ele alan Kadrocular sınıfsız, tezatsız ve dayanışmacı bir toplum temin etmek istemektedir. Bunun sağlanması için ise gerekli durumlarda devletin planlayıcı ve müdahaleci fonksiyonlarını devreye sokması gerektiğine dikkat çekmektedirler.

- Bireyselliğin sadece iktisadi alanda değil tüm toplumsal alanlarda göz ardı edilmesi gerektiğini savunmaktadır. Kadroculara göre ulusal sanayi kurma çabasında olan Türkiye Cumhuriyeti'nde devletçilik ilkesi ile milli yarar için bireylerin iktisadi hareketleri yasal düzenlemeler ile sinırlandırabilmelidir (Köker, 2007:194-195).

Kadro hareketinin devletçilik anlayışı, sosyal bir düzen olarak tüm toplumsal alanlara yayılmak istenmiştir. Devletçilik, tüm şahsi menfaatlerin üzerinde tutulmuştur (Keser, 1993:138). Böylesi bir devletçilik ilkesi hükümet tarafindan hiçbir dönemde politika haline getirilmemiştir. ${ }^{5}$ Kadronun ifade ettiği gibi sınıfsız bir toplum tam anlamıla olmadığ 1 gibi devletin Türk burjuvası yetiştirerek milli ekonomi oluşturma gayesi olduğu bilinmektedir (Keser, 1993:133).

\section{Kadro Dergisi ve Ahmet Ağaoğlu Arasındaki Devletçilik Polemiği}

Serbest Cumhuriyet Fırkası'nın kapanmasının ardından Ağaoğlu milletvekilliğini dönem sonuna dek bağımsız vekil olarak idame ettirmiştir. Siyasal alandan bir nebze olsun uzaklaşmak adına Ankara'dan ayrılarak İstanbul Darülfünun'da hukuk profesörlüğü yapmaya başlamıştır. Parti ve siyaset alanındaki etkinliğini yazarlığa bırakan Ağaoğlu düşüncelerini, eleştirilerini ve tartışmalarını bu doğrultuda şekillendirmiştir. Özellikle 1932-1933 yılları arasında Aydemir ile devletçilik üzerine olan tartışması uzun süre gündemde kalmıştır (Shissler, 2005: 314).

Ahmet Ağaoğlu ve Şevket Süreyya Aydemir siyasi, ekonomi ve toplumsal alana dair yorumlarını iki farklı pencereden yapmaktadır. Ağaoğlu liberal-milliyetçi kimliği ile tanınırken, Aydemir solcu gelenekten gelen Marksist anlayışın savunucusu olmuş bir isimdir (Shissler, 2005:124; Ertan, 1994: 35). Aydemir ve Ağaoğlu arasındaki tartışma 1931 yılında Şevket Süreyya Aydemir tarafından verilen bir konferansta başlayarak Cumhuriyet gazetesi ve Kadro dergisinde devam eder. Aydemir, Ağaoğlu'na yönelik eleştirilerini "İnkılap ve Kadro" isimli eserinde bir araya getirirken Ağaoğlu "Devlet ve Fert" adıyla bir kitap yayınlamıştır. İkili arasında inkılapçılık, demokrasi, milliyetçilik, hürriyet gibi pek çok kavram tartışılmıştır. İfade edilen bu kavramları Ağaoğlu bireyci bir tavır çerçevesinde ele alırken, Aydemir ferdi geri planda tutarak milli çıkarlar uğruna devlet müdahalesini savunmuştur (Ertan, 1994: 174-176). Tartışma, Ağaoğlu'nun Aydemir'e yönelik eleştirileri ile başlamış ve buna karşın Aydemir'in Ağaoğlu'na yönelik cevapları șeklinde uzun bir süre devam etmiștir ${ }^{6}$.

Ağaoğlu ve Aydemir arasındaki tartışmada dört ana konu yer almaktadır. Geri kalmışlığın nedenleri; devletçilik ve kalkınma ilişkisi; yöneten ve yönetilen ilişkisi; demokrasi, özgürlük, ülke menfaatleri ve sosyal adalet ilişkileridir. Tartışmanın iki kanadı da kendi fikir dünyası ve ideolojileri çerçevesince bu sorulara yanıt aramışlardır. Yönetim, ekonomi ve toplum meselelerinde Ağaoğlu siyasi ve kültürel minvalde değerlendirmeler yaparken (Hakl1, 2018:136); kadro hareketi kapitalist ve emperyalist düzen karşıtlı̆̆ temelinde ifadelerde bulunmuştur (Köker, 2007: 195).

Türkçülük- İslamcılık tartışmalarından sonra Ahmet Ağaoğlu'nun yer aldığı ikinci büyük tartışma 1930'lu yıllarda iç ve diş faktörlerin etkisi ile önem kazanan devletçilik üzerine olmuştur. Bu nedenle

\footnotetext{
${ }^{5}$ Ancak dönemin başvekili İsmet Paşa harekete olan desteğini Kadro dergisinin 22. Sayısında yayınlanan "Fırkamızın Devletçilik Vasfı" isimli yazı ile açık ve net bir şekilde ortaya koymuştur. Kadrocular kadar sert bir devletçi görüşü ifade etmese de ortak görüşlerini bu yazıda dile getirmiştir. Bkz: Kadro Dergisi, 1933: 4-8.

${ }^{6}$ Aydemir'in Ağaoğlu'na yönelik eleştirilerine "Kadro Dergisi'nin 1932 ve 1933 yılları arasındaki sayılarından, Ağaoğlu'nun eleştirilerine ise "Devlet ve Fert" isimli eseri ve 1933 yılında çıkardığı Akın Gazetesi'nden ulaşılabilir.
} 
devletçilik, Ağaoğlu ve Aydemir arasındaki tartışmanın temel konularından biridir. SCF’nin ilk üyesi olan Ağaoğlu devletçi olduğunu ifade etmiştir (Ağaoğlu, 1933:72). Ancak Ağaoğlu'nun ifade ettiği devletçilik, liberal-devletçiliktir. Bireyin yapamadığı işlerde devletin o işi üstlenmesi olarak tanımlanabilecek olan bu anlayış, tek parti CHP'sinde ve Kadro hareketinden oldukça farklıdır. Devlet müdahalesinin sınırlarının katı bir şekilde çizilmesi ve bireyin hürriyetine zarar veren müdahalelerden kaçınılması gerektiğini belirtmektedir. Devletin, bireyin gelişmesinde rol alması gerektiğini ve bunun için eğitim hizmetini tesis etmesini, güvenliğini sağlaması gerektiğini ifade etmektedir (Hakl1, 2018:51). $\mathrm{Bu}$ bağlamda Aydemir özelinde Kadro hareketinin devletçilik anlayışını eleştirir. Aydemir, milli kurtuluş hareketinin liberal ve bireyci kapitalizme karşı doğmuş bir hareket olduğunu ifade eder. Ağaoğlu'nun aksine milli ekonomik sistemle kalkınmanın mümkün olacağını bunun ise ancak devletin planlı ve örgütlü müdahaleleri dahilinde gerçekleşeceğini ileri sürmektedir (Ertan, 1994:175).

İlk olarak Aydemir'in 1931'de "İnkılabın İdeolojisi" adlı konferansta dile getirdiği ve sonrasında yine Aydemir'in 1932'de yayımladığı "Inkılap ve Kadro" adlı kitabında yer alan ilkelere göre Kadro hareketinin devletten beklentileri şunlardır;

- Dünyadaki ekonomik gelişmelere ayak uydurmak,

- Toplum adına ekonomiye müdahale etmek,

- Sermaye birikimini elinde toplamak ve milli çıkarlara uygun yatırımlarda kullanmak,

- Ekonomik alan ile ilgili kararları milli bir plan dahilinde almak (Bostanc1, 1990:54).

Liberal kanadın temsilci Ağaoğlu ile Marksist gelenekten gelen Kadro dergisinin devletçilik anlayışı çeşitli noktalarda farklı1ık göstermektedir. Devletçiliğin gerekli olacağı duruma dair Ağaoğlu, bireyin yetemeyeceği noktada devletin devreye girmesini savunurken; Kadro hareketi yazarlarınca devlet, milli çıkarlar doğrultusunda tüm alanlarda müdahaleci bir tutum sergileyebilmektedir. Kadroculara göre dünyada iki temel çelişki vardır. İlki, kapitalist ülkelerdeki sermaye sınıfı ve işçi sınıfı arasında, ikincisi ise metropoller ve sömürge-yarı sömürgeler arasındaki çelişkidir (Mutlu, 2011). Türkiye'de yarı sömürge konumda olması sebebiyle gelişmiş ülkelerde görülen farklı sınıfların çıkarlarını temsil eden partiler ortaya çıkmamaktadır. Bu nedenle Kadro hareketi ülkeyi elit kesimin yönetmesi gerektiğini ifade etmektedir. Elit yönetici tabakası ülkenin kalkınması için birey çıkarlarını göz ardı etmeli ve toplum çıkarlarının birey çıkarının üstünde olduğunu kabul etmelidir. (Sunar, 2004:519-520). Kadro ve Ağaoğlu'nun görüşlerinde farklılaşan bir diğer alanın bireyin çıkarları noktasında olduğu görülmektedir. Kadro milli çıkarları birey üzerinde ele alırken, Ağaoğlu gibi liberal isimler bireyi, bireysel hak ve özgürlükleri ön planda tutmaktadır. Bu hususta farklılık arz eden diğer konu, yönetici meselesidir. Kadro hareketince yönetim işi elitler aracılığıyla olmalıdır (Demirci, 2006: 46). Ağaoğlu ise çoğulcu, rekabetçi demokratik bir ortamın tesisi için mücadele etmektedir. Bireyin kendi kararını vermesi için eğitim konusuna dikkat çeken Ağaoğlu, devletçi bir tavır sergileyerek devletin eğitim hizmetini tüm halka sunmas1 gerektiğini ifade etmektedir.

Ağaoğlu son yıllarda Kadro' ya yönelik eleştirilerini sertleştirince Aydemir, kendisini “jurnalci” olarak nitelendirmiştir. Bu tanımlamaya karşın Ağaoğlu aşağıdaki sözler ile ikili arasındaki tartışmayı noktalamıştır.

"Bütün bunlardan anladım ki karşıma dikilen adam sadece bilgisi hiç, fakat yüksekten atıp tutan bir adam imiş. Aldanıp böyle birisile haftalarca meşgul olduğuma ve efkarı umumiyeyi meşgul ettiğime cidden müteessifim. (Ă̆goğlu, 1933: 134)."

Görüldüğü üzere devletçilik, Kadro hareketinde ve Ağaoğlu perspektifinde oldukça farklı ele alınmıştır. Kalkınmanın nasıl olacağı, devletin hangi alanda ön plana çıkacağı, birey çıkarları, devletin ekonomideki rolü, yönetimin kimde olacağı gibi çeşitli sorulara farklı cevaplar vermişlerdir. Pek tabi Kadro'nun çıkışındaki Marksist etki ile Ağaoğlu'nun zihin dünyasını şekillendiren liberalizm bu farklılaşmanın temel sebebidir. Marksist görüş̧e dayalı Kadro hareketi devletçiliği materyalist anlayış çerçevesince ele alırken, Ağaoğlu bireyi önceleyen, daha 1lımlı sayılabilecek, belli başlı noktalarda devletçilik ilkesini savunmaktadır. Kadro yazarlarından Aydemir, liberalizmi sınıflı bir toplum ile özdeşleştirip Ağaoğlu'nu eleştirerek sınıfsız bir milli devlet önerisinde bulunmuştur. Kemalizm'in temel gayesinin sınıfsız, dayanışmacı, tezatsız bir toplum oluşturmak olduğunu vurgulayarak Ağaoğlu'nun bu ideolojiye uymadığını ifade etmiştir. Ağaoğlu Devlet ve Fert eserinde inkılapçı, Kemalist ve devletçi olduğunu vurgularken bu konuda Kadrocular ile kendisi arasında derin farkların olduğunu belirtir (Ağaoğlu, 1933:72). İnönü her ne kadar Kadro hareketini destekleyici bir tutum içerisinde olsa da tüm alanlarda devlet müdahalesinin bulunduğu katı bir devletçilik ilkesi uygulanmamıştır. Nitekim bunda 
Celal Bayar'ın iktisat bakanı olmasının büyük payı vardır. Hükümetin Kadro tarzı devletçilik anlayışını benimsememesi, liberal izlerin hala parti içinde barındığı şeklinde yorumlanabilir. Bunun yanı sıra ülkedeki yabanci sermayeye duyulan ihtiyaç, özel teşebbüslerin tam anlamıla reddedilmemesi gibi hususlar karma bir devletçilik ilkesinin inşa edildiğinin göstergesidir.

\section{SONUC}

Savaştan mağlup ayrılmış ve buna bağlı olarak ekonomisi yıpranmış, idari alanı belirsizliklerle dolu olan Osmanlı Devleti yerini Türkiye Cumhuriyeti'ne bırakmıştır. Yeni devlet, belirleyeceği politikalar ile ekonomik enkazı kaldırmak istemiştir. Türkiye Cumhuriyeti kurulduğu ilk günden 1929 Ekonomik Buhranına değin özel teşebbüse dayalı bir kalkınma politikası izlemiştir. 1929 krizi ile ekonomi politikalarında köklü değişiklikler yapmıştır. Bu değişim devletçilik ilkesinin benimsenmesi yönünde olmuştur. Bu yeni ekonomi politikasında dikkat çeken en önemli husus, özel teşebbüsü reddetmeyip devletinde etkin konumda olduğu karma bir metodun kullanılmasıdır. Özel teşebbüs bazı yasal düzenlemeler ile sınırlandırılsa da hiçbir zaman tam anlamıyla reddedilmemiştir. Özel teşebbüs yatırımlarını yapmaya devam etmekte, devlet ise eksik alanlarda devreye girmektedir. Karma metodun bu özelliği ile Ağaoğlu'nun hangi alanlarda devletin ekonomiye dâhil olacağı ifadeleri örtüşmektedir. Benzer söylemlere Ağaoğlu'nda rastlanmaktadır. Bireyin yapamayacağı işlerde devletin üstlenmesi gerektiğini ifade etmektedir. Nitekim 1930 sonrası devletçiliğindeki uygulamalarında bu yönde seyrettiği görülmüştür.

Tek parti döneminin hâkim ideolojisi olan Kemalizm'i sosyalist açıdan yorumlayan Kadro hareketinde ise devletçilik ilkesi Ağaoğlu'ndan tamamen ayrışmaktadır. Ağaoğlu, karma devletçilik anlayışında olduğu gibi devletin belli alanlarda olması gerektiğini savunurken, Kadrocular milli çıkarlar doğrultusunda, devletin tüm alanlarda müdahaleci ve planlı bir yaklaşım sergilemesi gerektiğini ifade eder. Devletçilik ilkesinde ayrıştıkları bir diğer nokta ise bireye bakış açısıdır. Liberalizmin temsilcilerinden Ağaoğlu, birey çıkarına önem vermektedir. Kalkınma ancak bireye tanınan hak ve özgürlükler ile mümkün olacaktır. Kadrocular ise bireyi ve birey çıkarlarının göz ardı edilmesini, asıl olanın milli çıkarlar olduğu görüşünü desteklemektedir. İnönü her ne kadar Kadro hareketine 1lımlı gibi görünse de ülkenin kalkınmasında özel teşebbüse olan ihtiyaç olduğunun da bilincinde olmuştur. Bu sebeple, Ağaoğlu tarzı 1lımlı veya liberal devletçilik anlayışının izlerine rastlamak mümkündür. Kadro hareketinin ısrarla savunduğu planlı ve müdahaleci devlet anlayışı, ilk olarak 1933-1938 yılları arasında uygulanan Beş Yıllık Kalkınma Planı ile kendini göstermiştir. Sovyet Rusya'nın model alınarak hazırlandığı bu plan ile başarıya ulaşılmış ve kısa süre sonra ikincisi oluşturulmuştur. II. Dünya Savaşı'nın başlaması, Türkiye dahil tüm devletleri yeniden savaş ekonomisine yönlendirmiş ve planlı ekonomi çalışmalarını rafa kaldırtmıştır.

Ağaoğlu ve Kadrocuların 1932-1933 yılları arasında devletçilik üzerine yaptığı tartışmaların hükümet nezdinde de yankı uyandırdığı ifade edilebilir. Öyle ki II. Dünya Savaşına dek uygulanmaya çalışılan devletçilik anlayışında zaman zaman Ağaoğlu tarzı zaman zaman ise Kadro tarzı uygulamalara rastlamak mümkündür. İki farklı perspektifte uygulama alanı bulan devletçilik anlayışında başarılı olunan noktalar olmakla devletin ekonomik gücü, iş gücü ve Osmanlı Devleti’nden kalan mali sorunları sebebiyle beklenen başarının elde edilmesi güçleşmiştir.

\section{KAYNAKÇA}

Ağaoğlu, A. (1930), Serbest İnsanlar Ülkesinde, İstanbul Sanayiinefise Matbaası, İstanbul. Ağaoğlu, A. (1933), Devlet ve Fert, İstanbul Sanayiinefise Matbaası, İstanbul.

Ağaoğlu, S. (1998), Babamın Arkadaşları, İletişim Yayınları, İstanbul.

Aşçı, H. B. (2016), "Lozan Barış Antlaşması'nda Osmanlı Borçları Meselesi”, İnsan ve Toplum Bilimleri Araştırmaları Dergisi, Cilt 5, Sayı 6: 1649-1666.

Atalar, M. (2018), Ahmet Ağaoğlu (1869-1939), Oğuz-Türkmen Araştırmaları Dergisi, Cilt II, Sayı 2: 139-151.

Aydemir, Ş.S. (1932), İnkılap ve Kadro, İstanbul Milliyet Matbaası, İstanbul.

Berber, Ş. G. (2011), “Osmanlı'nın Son Döneminden Cumhuriyet'in İlk Yıllarına LiberalizmDevletçilik Çatışması”, Atatürk Araştırma Merkezi Dergisi, Cilt 27, Say1 80: 209-240.

Boratav, K. (2006), Türkiye'de Devletçilik, Savaş Yayınları, İstanbul.

Bostancı, N. (1990), Kadrocular ve Sosyoekonomik Görüşleri, Kültür Bakanlığı Yayınları, Ankara. 
Civelek, N. (2020), “Liberalizmin Dayanışma Yanlısı Savunusu: Ahmet Ağaoğlu'nda Durkheim Tesiri”, Doğumunun 150. Yılında Türk Dünyasının Görkemli İçmtimaî Siyasî Hadimi Ahmet Ağaoğlu Sempozyumu, 21-22 Ekim 2019, İstanbul.

Demirci, F. (2006), "Kadro Hareketi ve Kadrocular”, Dumlupınar Üniversitesi Sosyal Bilimler Dergisi, Say1 15: 35-54.

Dikmen, N. (2005), "Osmanlı Dış Borçlarının Ekonomik ve Siyasi Sonuçları", İktisadi ve idari Bilimler Dergisi, Cilt 19, Say1 2: 137-159.

Ercoşkun, B. (2019), “Tarihsel Bir Perspektiften Türkiye'de Liberalizm”. Akademik Bakış Dergisi, Sayı 72: $105-122$.

Ertan, T. F. (1994), Kadrocular ve Kadro Hareketi, T.C. Kültür Bakanlığg Milli Kütüphane Basımevi, Ankara.

Ezer, F. (2010), “1929 Dünya Ekonomik Krizi’nin Türkiye’ye Etkileri”, Fırat Üniversitesi Sosyal Bilimler Dergisi, Cilt 20, Say1 1: 427-442.

Gündoğdu, A. (2020), “Ahmet Ağaoğlu'nun Fikrî Gelişim Çizgisi”, Doğumunun 150. Yılında Türk Dünyasının Görkemli İçmtimaî Siyasî Hadimi Ahmet Ağaoğlu Sempozyumu, 21-22 Ekim 2019, İstanbul.

Hakl1, S. Z. (2018), “Ahmet Ağaoğlu'nun Batılılaşma Düşüncesinde Türkiye'nin Toplumsal Yapısı ve Kültürel Değişim”, Muhafazakar Düşünce Dergisi, Cilt 15, Sayı 14: 117-141.

Haklı, S. Z. (2018), "Erken Dönem Cumhuriyet'te Ahmet Ağaoğlu'nun Kemalizm'i Liberal Perspektiften Yorumlama Çalışmaları”, Liberal Düşünce Dergisi, Cilt 23, Sayı 90: 35-57.

Hekimoğlu, V.S. (2018), "Gazeteci Kimliğiyle Ahmet Ağaoğlu", Bitlis Eren Üniversitesi Akademik İzdüşüm Dergisi, Cilt 3, Sayı 1: 47-59.

İnönü, İ. (1933), "Fırkamızın Devletçilik Vasf1", Kadro Dergisi, Sayı 22: 4-8.

Kahraman, S. (2005), “(1929-1939) İktisadi Devletçilik ve Sanayileşme Politikaları”, Basılmamış Yüksek Lisans Tezi, İstanbul Üniversitesi Sosyal Bilimler Enstitüsü, İstanbul.

Kayabaş, E. (2012), "Bir Yavuz Hukukçu: Ahmet Ağaoğlu”, İstanbul Üniversitesi Hukuk Fakültesi Mecmuas1, Cilt 70, Say1 1: 441-452.

Kepenek, Y. (1995), Türkiye Ekonomisi, Remzi Kitapevi, İstanbul.

Keser, İ. (1993), Türkiye'de Siyaset ve Devletçilik, Gündoğan Yayınları, Ankara.

Köker, L. (2007), Modernleşme Kemalizm ve Demokrasi, 10.Baskı, İletişim Yayınları, İstanbul.

Mutlu, S. (2011), "Düşünce ve Uygulamada Devletçilik". Türk Yurdu Dergisi, Cilt 31, Sayı 292. Erişim Adresi: https://www.turkyurdu.com.tr/yazar-yazi.php?id=1740

Orhan, A. (2009), "Tek Partili Yilların Ekonomi-Politiği ve Kadro Hareketi”, Kocaeli Üniversitesi Sosyal Bilimler Enstitüsü Dergisi, Cilt 17, Sayı 1: 120 - 147.

Özavc1, H. O. (2014). "Differing Interpretations of La Conscience Collective and "The Individual" in Turkey: Émile Durkheim and The Intellectual Origins of The Republic", Journal of the History of Ideas, Volume 75, No 1: 113-136.

Pamuk, Ş. (2012), Osmanlıdan Cumhuriyete Küreselleşme, İktisat Politikaları ve Büyüme, Gençlik Kitapevi, İstanbul.

Sağlam, D. (1981), "Devletçilik İlkesinin Gelişmesi ve Günümüzdeki Sonuçları”, Ekonomik Yaklaşım Dergisi, Cilt 2, Say1 4: 71-97.

Shissler. A. H. (2005), İki İmparatorluk Arasında Ahmet Ağaoğlu ve Yeni Türkiye, İstanbul Bilgi Üniversitesi Yayınları, İstanbul.

Sunar, L. (2004), "Kadro Dergisi/Hareketi ve Etkileri”, Türkiye Araştırmaları Literatür Dergisi, Cilt 2, Say1 1: 511-526.

Türk $\quad$ Dil Kurumu $\quad$ Genel Türkçe $\quad$ Sözlük. http://www.tdk.gov.tr/index.php?option=com_gts\&arama=gts\&guid=TDK.GTS.5cd6a2fd8c869 1.65470298. 23.04.2019 tarihinde erişildi.

Özlü, H. (2009), “Atatürk Dönemi Ekonomi Uygulamaları ve Savunma Sanayisindeki Gelişmeler”, Askeri Tarih Araştırmaları Dergisi, Cilt 7, Sayı 13: 119-143.

Özyurt, H. (1981), "Atatürk Dönemi, Birinci ve İkinci Beş Yıllık Sanayileşme Planları ve Türk Ekonomisindeki Yapı Değişikliğine Etkileri (1933-1938)", Sosyoloji Konferansları, Sayı 19: 119-148.

Uzun, H. (2016), "Cumhuriyet Halk Partisi Kongrelerinde Devletçilik Tartışmaları (1931-1947)", Avrasya İncelemeleri Dergisi, Cilt 5, Sayı 2: 273-305. 
Yılmaz, M. (1993), “Ahmet Ağaoğlu ve Liberalizm Anlayıșı”, Türkiye Günlüğü, Sayı 23: 56-71.

Yüce, N. (1988), "Ağaoğlu Ahmet (1869-1939) Türk Gazetecisi ve Siyaset Adamı", TDV İslam Ansiklopedisi, Cilt 1: 464-466.

Yücel, H. (2017), Cumhuriyet Ekonomisinin Kuruluşu ve Gelişimi, Türkiye Barolar Birliği Yayınları, Ankara. 
